\title{
COMPARISON OF MEASURED AND PREDICTED CHARACTERISTICS OF THE ELK RIVER REACTOR
}

\author{
J. R. FISHER* and E. D. KENDRICK* \\ Atomic Energy Division, Allis-Chalmers Manufacturing Company, \\ Bethesda, Maryland
}

\begin{abstract}
The Elk River Reactor is a second-round, $\mathrm{ThO}_{2}-\mathrm{UO}_{2}$ fueled, stainless-steel clad, boiling water reactor built by Allis-Chalmers Manufacturing Company under contract to the U. S. Atomic Energy Commission for the Rural Cooperative Power Company. One of the stated objectives of the reactor is the demonstration of the thorium cycle. The final physics design and pre-start-up analysis were done in 1958 to 1962 . The reactor was loaded in 1963, reached full power in 1964, and shut down for its first refueling in April 1966. At the time of shutdown, the core had achieved an average burnup of $7040 \mathrm{Mwd} /$ metric ton. Agreement between predicted and observed performance was excellent throughout the core life.
\end{abstract}

\section{CORE DESCRIPTION}

The Elk River Reactor (ERR) is a natural-circulation indirect-cycle system that feeds the secondary steam to a coal-fired superheater and thence to the turbine generator. Table 1 shows the pertinent parameters of the final mechanical design of the core. Figure 1 is a cross section of the core and pressure vessel.

Sixteen of the 164 fuel-element positions in the core are occupied by dummy elements. These elements prevent coolant bypass of the operating elements and can be loaded with fuel if further design requirements necessitate it.

The reactor fuel is a mixture of thoria $\left(\mathrm{ThO}_{2}\right)$ and $93.5 \%$ enriched urania $\left(\mathrm{UO}_{2}\right)$. The present core contains 128 regular and 20 spiked

* Present address: Nuclear Associates International Corporation, 12601 Twinbrook Parkway, Rockville, Maryland. 


\section{DISCLAIMER}

This report was prepared as an account of work sponsored by an agency of the United States Government. Neither the United States Government nor any agency Thereof, nor any of their employees, makes any warranty, express or implied, or assumes any legal liability or responsibility for the accuracy, completeness, or usefulness of any information, apparatus, product, or process disclosed, or represents that its use would not infringe privately owned rights. Reference herein to any specific commercial product, process, or service by trade name, trademark, manufacturer, or otherwise does not necessarily constitute or imply its endorsement, recommendation, or favoring by the United States Government or any agency thereof. The views and opinions of authors expressed herein do not necessarily state or reflect those of the United States Government or any agency thereof. 


\section{DISCLAIMER}

Portions of this document may be illegible in electronic image products. Images are produced from the best available original document. 
Table 1

ERR DESIGN DATA

\begin{tabular}{|c|c|}
\hline \multicolumn{2}{|l|}{ Materials } \\
\hline Fue1 & $\mathrm{UO}_{2}-\mathrm{ThO}_{2}$ mixture \\
\hline \multicolumn{2}{|l|}{ Fuel enrichment in ${ }^{235} \mathrm{U}$} \\
\hline Regular elements & $4.3 \mathrm{wt} . \%$ of total $\mathrm{U}$ and $\mathrm{Th}$ \\
\hline Spiked elements & $5.2 \mathrm{wt} . \%$ of total $\mathrm{U}$ and $\mathrm{Th}$ \\
\hline Cladding & 304L stainless steel \\
\hline Boron content of cladding & $600 \mathrm{ppm}$ natural boron \\
\hline Structure & Zircaloy-2 \\
\hline Followers & Zircaloy-2 \\
\hline Moderator and coolant & Light water \\
\hline Control rods & 2.2 to $2.3 \%$ boron stainless steel \\
\hline \multicolumn{2}{|l|}{ Core dimensions } \\
\hline Active height & $60 \mathrm{in.}$ \\
\hline Mean diameter & $60 \mathrm{in.}$ \\
\hline \multicolumn{2}{|l|}{ Fuel-element cold dimensions } \\
\hline Fuel-pellet diameter & $0.407 \mathrm{in.}$ \\
\hline Fuel-pellet length & $0.50 \mathrm{in}$ \\
\hline $\mathrm{ThO}_{2}-\mathrm{UO}_{2}$ density (average) & $9.53 \mathrm{~g} / \mathrm{cm}^{3}$ \\
\hline Clad tubing, inside diameter & $0.412 \mathrm{in}$. \\
\hline Clad tubing, outside diameter & 0.452 in. \\
\hline \multicolumn{2}{|l|}{ Fuel tube center-to-center pitch: } \\
\hline Normal & $0.75 \mathrm{in.}$ \\
\hline Diagonal & $1.06 \mathrm{in.}$ \\
\hline \multicolumn{2}{|l|}{ Control rods } \\
\hline Number & 13 \\
\hline Shape & Cruciform \\
\hline Span & $14.875 \mathrm{in}$. \\
\hline Thickness & $0.25 \mathrm{in.}$ \\
\hline Effective length when fully inserted & $56 \mathrm{in.}$ \\
\hline \multicolumn{2}{|l|}{ Followers } \\
\hline Number & 13 \\
\hline Shape & Cruciform \\
\hline Span & $14.5 \mathrm{in}$. \\
\hline Thickness & $0.25 \mathrm{in}$. \\
\hline \multicolumn{2}{|l|}{ Maximum length in the core } \\
\hline when rods are fully withdrawn & $45 \mathrm{in.}$ \\
\hline \multicolumn{2}{|l|}{ Shrouds } \\
\hline Length & $7.625 \mathrm{in}$. \\
\hline Width & 7.625 in. \\
\hline Thickness & $0.0625 \mathrm{in.}$ \\
\hline
\end{tabular}

elements. On the basis of total thoria and urania, the ${ }^{235} \mathrm{U}$ content is $4.3 \mathrm{wt} . \%$ for the regular elements and $5.2 \mathrm{wt} \%$ for the spiked elements. The mixture is defined by the following weight ratio:

$\frac{{ }^{235} \mathrm{U} \text { (metal) }}{\mathrm{Th}+{ }^{235} \mathrm{U}+{ }^{238} \mathrm{U} \text { (metal) }}$

The fuel pins are clad with free-standing, annealed 304L stainless steel which initially contained $600 \mathrm{ppm}$ of natural boron. 


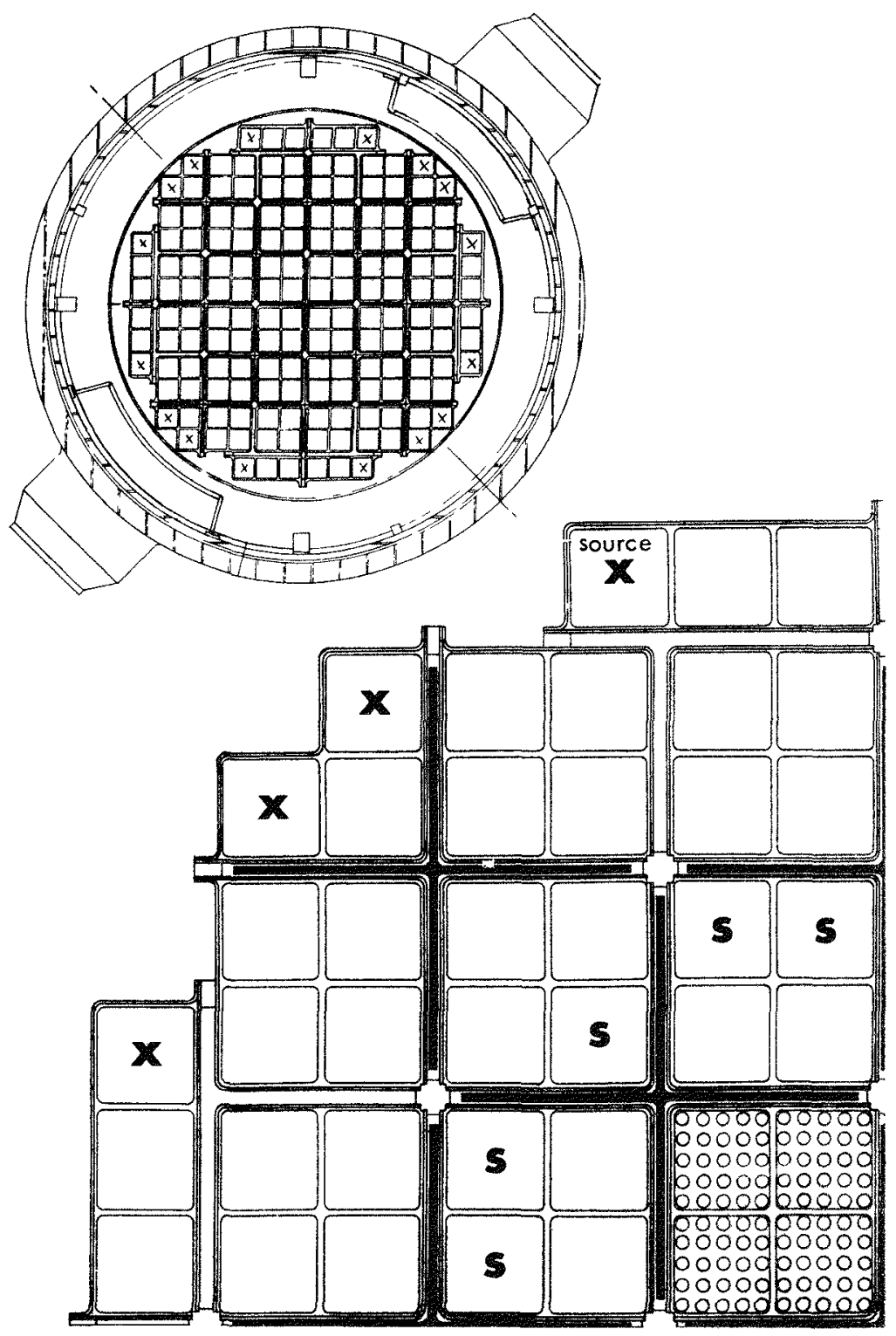

Fig. 1-Core loaded with 128 regular elements enriched 4.3\%, 20 spiked elements enriched $5.2 \%$, and 16 dummy elements. $X$, dummy elements; $S$, spiked elements. 
The fuel element incorporates a 5 by 5 array of 25 fuel rods; the center rod of each element is interchangeable with a borated or a sample-bearing stainless-steel rod. The boron pins provide flexibility to reduce reactivity, and the sample tubes allow irradiation of specimens similar to the material of the control rods. The final assembled core did not require boron pins; but in eight elements the center pin was replaced with a sample tube.

The core is controlled by 13 boron-stainless-steel cruciform control rods mounted on the bottom of the reactor vessel. They are withdrawn upward; thus reactivity is decreased by downward movement and increased by upward movement. During normal operation the center rod is used as a regulating rod and the others are used as shim rods.

The cruciform rods are guided into the spaces between the individual cells by Zircaloy-2 shrouds welded to the cruciform Zircaloy-2 support posts.

\section{COMPARISON OF ANALYTICAL METHODS WITH EXPERIMENT}

The models and methods used in analyzing the reactor have undergone a number of evolutionary changes since the beginning of design. These are briefly reviewed chronologically, and the adequacy and applicability of each are examined.

\section{Design-phase Methods}

During the design phase, from 1958 to 1960 , such items as the number of control rods, the wt. $\%{ }^{235} \mathrm{U}$, the amount and placement of the burnable poison, reactivity inventory, and power and void distributions were determined. During this phase the Westcott-type crosssection model ${ }^{1}$ was utilized for predicting reaction rates. The cross section is defined as

$$
\sigma=\frac{\sigma_{0}[\mathrm{~g}+\mathrm{rs}]}{1-\mathrm{br}} \sqrt{\frac{\pi \mathrm{T}_{0}}{4 \mathrm{~T}_{\mathrm{n}}}}
$$

where $\sigma_{0}=2200-\mathrm{m}$ absorption cross section

$\mathrm{T}_{\mathrm{n}}=$ neutron temperature

$\mathrm{g}=$ non $-1 / \mathrm{v}$ factor for the thermal group

$\mathbf{s}=$ non $-1 / \mathrm{v}$ factor for the epithermal group

$r=$ spectral indices

The spectrum was taken as a hardened Maxwellian in the thermal group and as $1 / \mathrm{E}$ in the epithermal group. 
The model used ${ }^{2}$ incorporated a smoothing function to join the thermal and epithermal spectra. This function, adopted from Campbell and Freemantle, ${ }^{3}$ was linear from 1 to $3.5 \mathrm{kT}$, constant from 3.5 to $5 \mathrm{kT}$, and proportional to $1 / \mathrm{E}$ above $5 \mathrm{kT}$. The $\mathrm{g}$ and $\mathrm{s}$ values for all isotopes of interest in both thorium and uranium cycles had been recalculated by using this spectrum assumption.

The choice of this cross-section model was one of expediency. The spectral programs accessible at that time did not include thorium, ${ }^{233} \mathrm{U}$, etc., and neither the time nor the inclination was available to amend the programs. The model proved very useful and is still incorporated into one portion of the current calculational procedure.

The flux-weighting factors necessary for reactivity analysis were obtained for the $\mathrm{ThO}_{2}-\mathrm{UO}_{2}$, the cladding, and the water inside the shroud by the so-called grey-cylinder approach, a method suggested by Pershagen and Carlvik. " The flux-weighting factors for the shrouds, the control-rod followers, and the water channels were determined from the two-group two-dimensional diffusion-theory calculations.

Power distributions were calculated by using the usual one-and two-dimensional diffusion-theory programs. Iterations between the void-distribution analysis and power-distribution analysis were done until convergence was obtained.

\section{Pre-start-up Phase}

In the period between final design and criticality, spectral programs were obtained which contained the thorium-chain isotopes. Average cross sections were determined by using the codes GAM-I for the fast groups ${ }^{5}$ and TEMPEST-II for the thermal group. ${ }^{6}$ Disadvantage factors were calculated by using a $\mathrm{P}_{3}$ program, and reactivity inventories were reinvestigated. The predictions of cold excess $\mathrm{k}$ and reactivity in temperature, voids, and xenon agreed with those of the design phase.

\section{Initial Fuel Loading and 100\% Power Results}

Cold Results The initial core loading consisted of 148 regular fuel elements $\left(4.3\right.$ wt. $\left.\%{ }^{235} \mathrm{U}\right)$. The presence of boron pins that could be interchanged with the center pin of each element and 22 spiked elements $\left(5.2\right.$ wt. $\left.\%{ }^{235} \mathrm{U}\right)$ that could be interchanged with the regular elements made it possible to adjust reactivity. This capability was built in to account for calculational uncertainties since the reactor was built without benefit of a critical experiment and contained features, such as the thorium and the burnable poison in the cladding, which differed from other boiling-water reactors. 
The clean, cold excess $\mathrm{k}$ was determined by rod calibration as a function of the number of elements in the core and by boric acid measurement with the fully loaded core. The reactivity thus measured for the 148 regular elements was $9.3 \%$. The predicted value was $11.2 \% \rho$, about $2 \% \Delta \rho$ higher than the measured value.

Examination of the data obtained by boric acid measurement indicated that part of the difference could be attributed to underestimation of the parasitic absorption in the cladding and moderator; i.e., since the actual worth of the boric acid was greater than predicted, it was reasonable to believe that the flux in the moderator was greater than predicted. Foil measurements between the pins substantiated this.

To investigate this analytically, a thermal multigroup calculation was done by utilizing, first, TEMPEST and $\mathrm{P}_{3}$ program and, second, TEMPEST and the grey-cylinder approach of Ref. 4. Cross sections inside the shroud were determined for use in spatial calculations, and two-dimensional three-group analysis was redone.

To illustrate the difference in reactivity prediction by the thermal single group and the thermal multigroup, the familiar thermal utilization was calculated by both methods for the fuel, the cladding, and the water inside the shroud box. These results are shown in Table 2. The uncertainties in such areas as the epithermal parameters of zirconium, etc., appear to be self-canceling, and the difference between the predicted and observed reactivity can be attributed in the most part to the disadvantage or flux-weighting factors.

Table 2

EFFECT OF ENERGY-SPACE SEPARABILITY

\begin{tabular}{|c|c|c|c|}
\hline \multirow[b]{2}{*}{ Nethod } & \multirow{2}{*}{$\begin{array}{l}\text { Thermal } \\
\text { group structure }\end{array}$} & \multicolumn{2}{|c|}{ Thermal } \\
\hline & & Utilization & $\Delta \mathrm{f} / \mathrm{f}$ \\
\hline \multirow[t]{2}{*}{ Grey cylinder ${ }^{4}$} & Single group & 0.7842 & \\
\hline & Multigroup & 0.7682 & $2.03 \%$ \\
\hline \multirow{2}{*}{$\mathrm{P}_{3}$} & Single group & 0.7894 & \\
\hline & Multigroup & 0.7754 & $1.78 \%$ \\
\hline
\end{tabular}

The difference between a thermal single-group model and a thermal multigroup model was not expected to be so great for fullpower conditions (of the order of $1 \%$ ). Thermal analysis done during the pre-start-up phase predicted that the steam void fraction in the core would be higher than earlier design values. To compensate for this and for the difference in predictions previously mentioned, 20 spiked elements were loaded as shown in Fig. 1. This increased the reactivity by about $1.2 \%$. The spiked and regular cores were recalcu- 
lated by use of a two-dimensional diffusion-theory program (PDQ), with three-group parameters obtained from the spectral programs, and the described averaging process in the thermal group. Agreement between these results, as shown in Table 3 , is much better. The only difference between this model and that of the pre-start-up period is in the treatment of the flux weighting of the fuel-pin cell.

Table 3

REACTIVITY OF UNRODDED CORE

\begin{tabular}{ccc}
\hline Core & Calculated & Measured \\
\hline Spiked & $10.1 \%$ & $10.5 \%$ \\
Regular & $8.7 \%$ & $9.3 \%$ \\
\hline
\end{tabular}

Results at $100 \%$ Power The mode of control-rod operation during power escalation is to keep the center rod inserted and to withdraw the remaining 12 rods in a bank. At full power and equilibrium xenon, the 12-rod bank is fully withdrawn, and the center rod is partially withdrawn.

Table 4

REACTIVITY LOSSES AT FULL POWER

\begin{tabular}{|c|c|c|}
\hline & Predicted, $\Delta \mathrm{k}$ & Observed, $\Delta \mathrm{k}$ \\
\hline Temperature & 0.013 & 0.010 \\
\hline Xenon & 0.023 & 0.025 \\
\hline Voids plus Doppler & 0.035 & 0.038 \\
\hline Total & 0.071 & 0.073 \\
\hline
\end{tabular}

In Table 4 the reactivity losses at full power, as predicted by the methods used in the design and pre-start-up phases, are compared with the observed values. This agreement indicates that the model and methods used in the design and pre-start-up phases were adequate for this type of prediction. However, they are cumbersome and inconvenient in some areas; for example, the void-power analysis is done by iteration, and three-dimensional power distributions are obtained by combining one- and two-dimensional analyses or by $\mathrm{R}-\mathrm{Z}$ calculations where rods are treated unsatisfactorily. To improve this, a new calculational model was adapted and verified during criticality and power escalation. 


\section{Post-start-up Phase}

The model adapted during start-up and currently in use represents the reactor as a one-group three-dimensional mock-up with coupled power and void calculations. This type of representation is accomplished by use of the FLARE program, ${ }^{7}$ which represents the reactor core as a series of three-dimensional cells or nodes; it is necessary

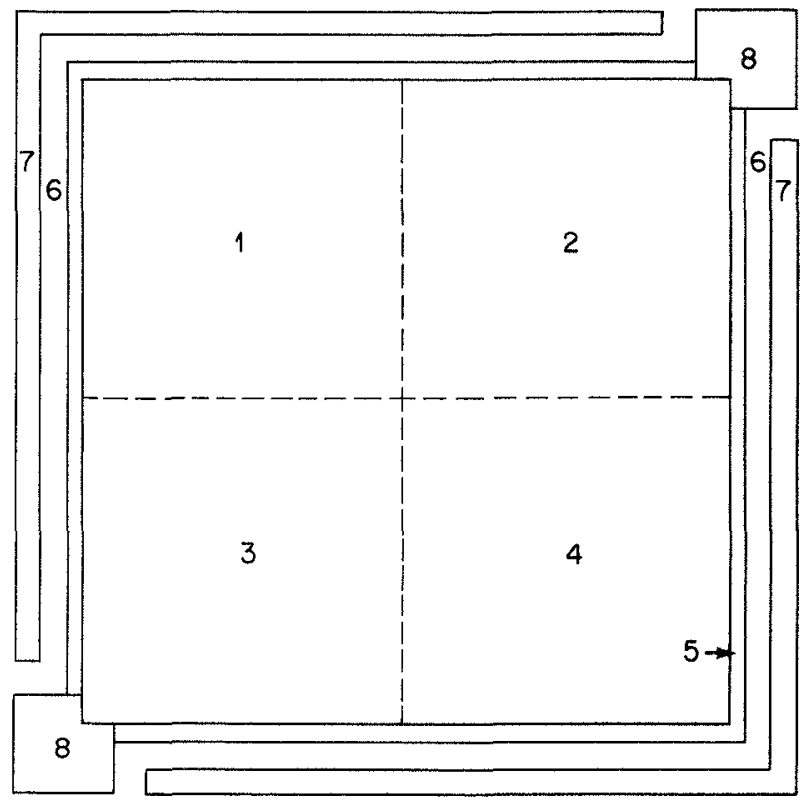

Fig. 2-Control-cell layout. 1 to 4, Fuel elements. 5, Zirconium shrouds. 6 , Water channel. 7, Control-rod or zirconum follower. 8, Zirconium posts.

to determine certain parameters externally. The physics input requires the control-rod-cell infinite multiplication factor and migration area as a function of void fraction, control-rod fraction, and fuel exposure. Figure 2 shows a typical control-rod cell. These parameters are necessary for the various types of elements that may be in the core, for example, the spiked and regular elements. The thermal and hydraulic input requires the degree of subcooling, the total recirculation flow rate, the inlet velocity distribution, and the void fractionsteam quality correlation for the conditions of interest. The reflector is treated by means of an albedo that is also input.

The input physics parameters, $\mathrm{k}_{\infty}$ and $\mathrm{M}^{2}$, were determined from a three-group two-dimensional representation of the control-rod cell. The thermal spectrum and resulting cross sections were calculated 
by using the TEMPEST-II program. A thermal multigroup transport calculation was done for the fuel-pin cell to obtain the average thermal cross sections of the fuel element. Cross sections for the upper two energy groups were obtained by using the GAM-I program. The control rods were represented by equivalent diffusion parameters, and the PDQ-2-90 code was used for the two-dimensional analysis. Threegroup calculations were done for the unrodded, one-rod-in, and tworods-in cases vs. temperature and void fraction.

Comparison with Cold Results The FLARE model can be normalized to a more sophisticated calculation or to experimental data in several ways, the most obvious being the variation of the reflector albedo. This was the method chosen for the ERR core. The normalization was done to the measured cold reactivity of the unrodded, uniformly loaded core containing 148 elements of $4.3 \mathrm{wt} . \%{ }^{235} \mathrm{U}$. After this normalization calculations of a number of observed critical rod configurations were made. Since this type of comparison does not involve data reduction or interpretation, it offers the best opportunity to test the complete calculational model. Figure 3 shows the rod locations, and Table 5 gives

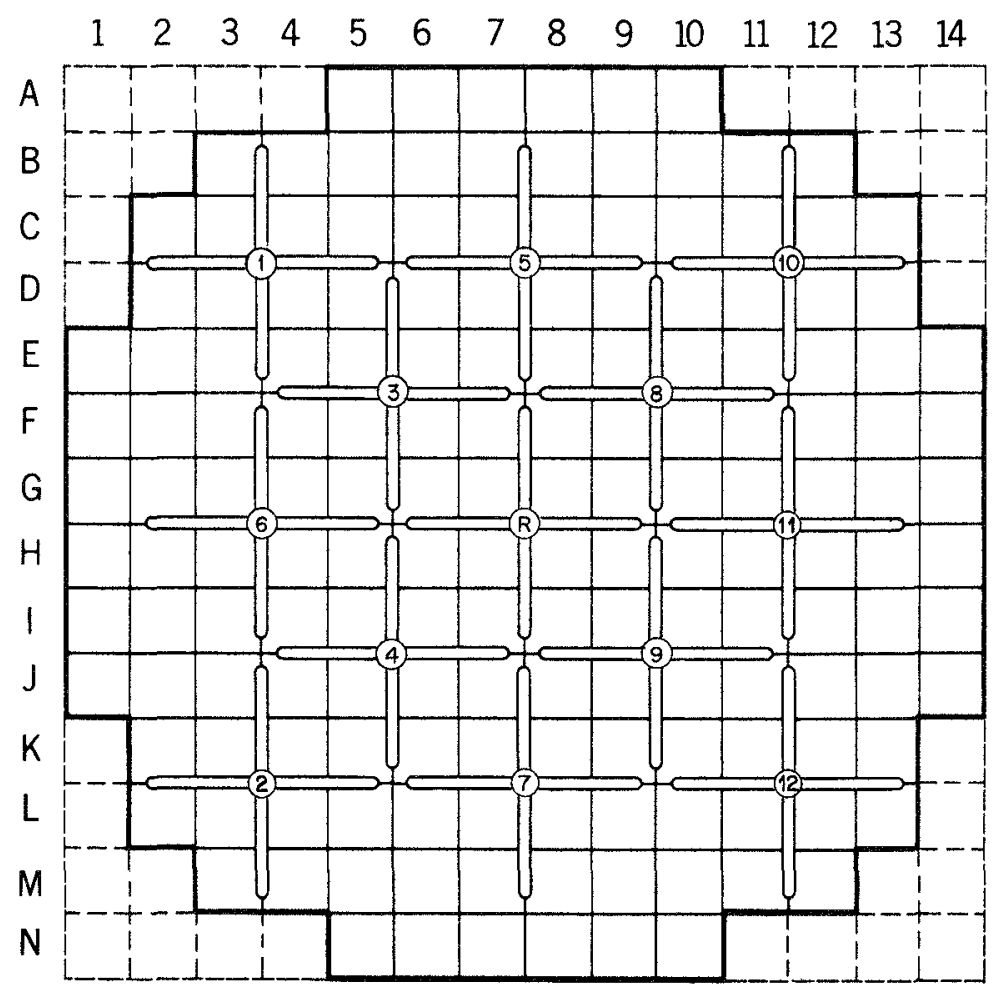

Fig. 3-Core layout. 
COLD-CORE RESULTS

\begin{tabular}{|c|c|c|}
\hline \multirow[b]{2}{*}{ Rod configuration } & \multicolumn{2}{|c|}{ Effective multiplication factor } \\
\hline & Calculated & Measured \\
\hline \multicolumn{3}{|c|}{ A. Uniform Core } \\
\hline Unrodded & $1.103^{*}$ & 1.103 \\
\hline All rods at $13.69 \mathrm{in}$. & 1.002 & 1.00 \\
\hline No. $R$ out, bank at 12.74 in. & 1.001 & 1.00 \\
\hline No. 5 out, bank at 12.69 in. & 1.004 & 1.00 \\
\hline No. 8 out, bank at $12.89 \mathrm{in}$. & 1.002 & 1.00 \\
\hline Nos. $5,10, \mathrm{R}$, and 11 at $25.20 \mathrm{in}$ & & \\
\hline No. 8 at 14.69 in. & 1.006 & 1.00 \\
\hline Nos. $5,6,7$, and 11 out & 0.995 & 0.998 \\
\hline \multicolumn{3}{|c|}{ B. Final Core } \\
\hline Unrodded & 1.117 & 1.117 \\
\hline All rods at $12.37 \mathrm{in}$. & 1.001 & 1.00 \\
\hline No. $R$ out, bank at 11.50 in. & 1.002 & 1.00 \\
\hline No. 5 out, bank at 10.43 in. & 1.006 & 1.00 \\
\hline Nos. 11 and 12 at $49.63 \mathrm{in.}$ & 1.006 & 1.00 \\
\hline \multicolumn{3}{|c|}{ C. Reactivity Insertion } \\
\hline $\begin{array}{l}\text { Nos. } 5,10, \mathrm{R} \text {, and } 11 \text { at } 25.20 \mathrm{in} . \\
\text { No. } 8 \text { at } 14.69 \text { in. } \\
\text { Nos. } 5,10, \mathrm{R} \text {, and } 11 \text { at } 20.14 \mathrm{in.}\end{array}$ & $43.9 \varphi /$ in. & 39 c $/$ in. \\
\hline No. 8 at 13.24 in. & $46 \mathrm{c} /$ in. & $42 \mathrm{c} / \mathrm{in}$ \\
\hline
\end{tabular}

*Normalized to this value.

the comparative results. Part $\mathrm{A}$ of the table shows the core data for the 148 regular elements. The calculated and measured values agree within $0.6 \%$ for all cases. Part $B$ of the table shows data for the final core. These later configurations were calculated with no further normalization; i.e., the only normalization done for any of the analysis was for the unrodded regular core. These calculations also agree to within $0.6 \%$ of the measured values.

One other type of calculation was performed on the cold core, i.e., reactivity insertion due to rod movement (see part $C$ of Table 5). This was done for abnormal rod configurations as well as for the 13-rod bank. The comparison of calculated with the measured values is also given in Table 5.

Comparison with Partial-and Full-power Results The analysis was extended to the hot operating core. During the initial approach to full power, measurements were taken of the rod positions vs. power level at the equilibrium xenon condition. The results of calculations performed for these rod configurations and conditions are shown in Table 6 . The 
Table 6

HOT-OPERATING-CORE RESULTS*

\begin{tabular}{|c|c|c|c|c|c|}
\hline \multirow[b]{2}{*}{ Condition } & \multirow[b]{2}{*}{ Rod configuration } & \multicolumn{2}{|c|}{$\begin{array}{c}\text { Effective multiplication } \\
\text { factor }\end{array}$} & \multicolumn{2}{|c|}{ Power coefficient } \\
\hline & & Calculated & Measured & Calculated & Measuied \\
\hline $\begin{array}{l}\text { Hot zelo } \\
\text { power }\end{array}$ & $\begin{array}{l}\text { No } 6 \text { inserted, } \\
\text { bank at } 199 \text { in }\end{array}$ & 10007 & 100 & & \\
\hline $20 \mathrm{Mw}(\mathrm{t})$ & $\begin{array}{l}\text { No } 6 \text { inserted } \\
\text { bank at } 279 \text { in }\end{array}$ & 10005 & 100 & & \\
\hline $40 \mathrm{Mw}(\mathrm{t})$ & $\begin{array}{l}\text { No } 6 \text { inserted } \\
\text { bank at } 474 \text { in }\end{array}$ & 10047 & 100 & & \\
\hline $582 \mathrm{Mu}(\mathrm{t})$ & $\begin{array}{c}\text { Bank withdrawn } \\
\text { No } 6 \text { at } 17 \text { I }\end{array}$ & 10003 & 100 & $103 \mathrm{C} / \mathrm{mw}$ & $12 \mathrm{c} / \mathrm{mw}$ \\
\hline
\end{tabular}

* Final core equilibi ium xenon

nominal hot, zero-power condition with no xenon was calculated to $01 \% \Delta \mathrm{k}$ The same accuracy was obtained by the $20 \mathrm{Mw}(\mathrm{t})$ condition Because of the testing requirements, the measurements for $40 \mathrm{Mw}(\mathrm{t})$ and above included some samarum and protactinium buildup This was not accounted for in the $40 \mathrm{Mw}(\mathrm{t})$ measurements but was included in the full-power measurements At the time of the full-power measurement, there were approximately 20 equivalent full-power days of operation, or $07 \% \Delta \mathrm{k}$ in samarium and protactinium

At the end of the initial 28-day power run, the reactor was shut down for a 3 -month period The gain in reactivity due to protactinium decay and the resultant ${ }^{235} \mathrm{U}$ buldup was $59 \mathcal{4}$, the predicted gain was $57 \mathrm{c}$

As stated previously, the full-power mode of operation is to have the 12-rod bank fully withdrawn and to follow reactivity losses by movement of the center rod The position of the center rod vs $\mathrm{Mwd} /$ metric ton was predicted by using this same calculational model An additional input, $\mathrm{k}_{\infty}$ vs time, had to be determined externally The isotopic variation with time was predicted by use of a point-depletion Thorıum-Uranium Recycle Analysis Program (TURAP) that utilizes the Westcott model ${ }^{1}$ for effective cross sections The depletion program redetermines the spectral index and hence effective cross sections as well as isotopic number densities at specified time steps.

Radioactive members of fission-product decay chains were divided into two groups, ${ }^{8}$ those which decay instantly and those which do not decay at all Also, all isotopes with

$$
\mathrm{y} \sigma_{0}<0.001
$$

where $\mathrm{y}$ is fractional yield and $\sigma_{0}$ is $2200-\mathrm{m}$ cross section, were 


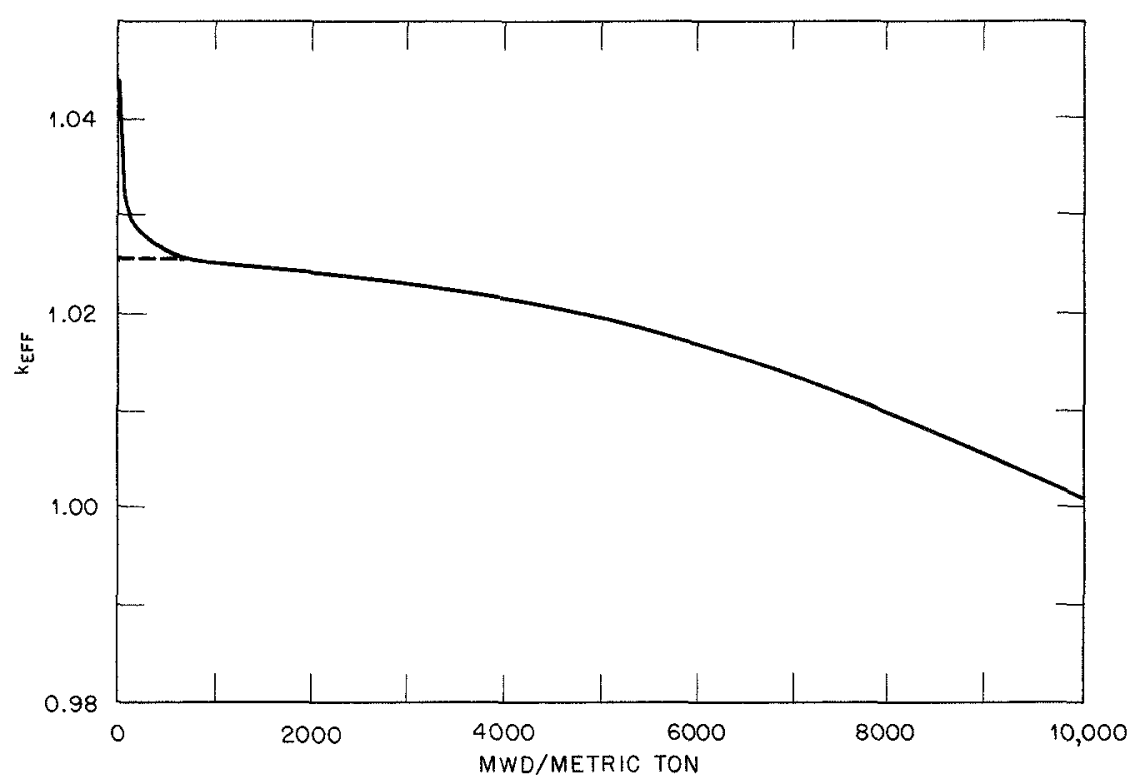

Fig. 4-Graph showing $K_{\text {eff }}$ vs. uniform exposure.

eliminated. This left a list of 59 first-order isotopes (those formed directly in fission). In addition, 12 of the most important second-order isotopes (those formed by burnup of the 59 primary isotopes) were considered. The number densities of these isotopes were calculated vs. flux time, and the cross sections were then compiled into an effective one-group cross section that varies with irradiation time and spectral index for use in the point-depletion analysis.

A graph of $\mathrm{k}_{\text {eff }}$ vs. time predicted by the TURAP program is given in Fig. 4. Figure 5 shows the predicted and observed rod positions as a function of irradiation time. The reactor was shut down for refueling on Apr. 15, 1966. At the time of shutdown, the position of the center rod was $59 \mathrm{in}$. from the bottom of the core, and the average burnup was $7040 \mathrm{Mwd} /$ metric ton. The agreement between the predicted and observed performance was excellent throughout the core life.

The reactor will be refueled in May 1966, with approximately one-third of the fuel being replaced. The removed fuel will have a burnup of about $9000 \mathrm{Mwd} /$ metric ton. The average burnup of the first core with the fuel-cycle program now envisioned will be about 11,000 Mwd/metric ton. Present plans call for the first removed fuel to be reprocessed and refabricated in the PCUT plant in Italy for eventual recycle into the ERR core. The second core fuel is 4.4 wt.\% uranium in thorium with the burnable poison eliminated. The geometric characteristics are very similar to those in Table 1 . The objective was to 


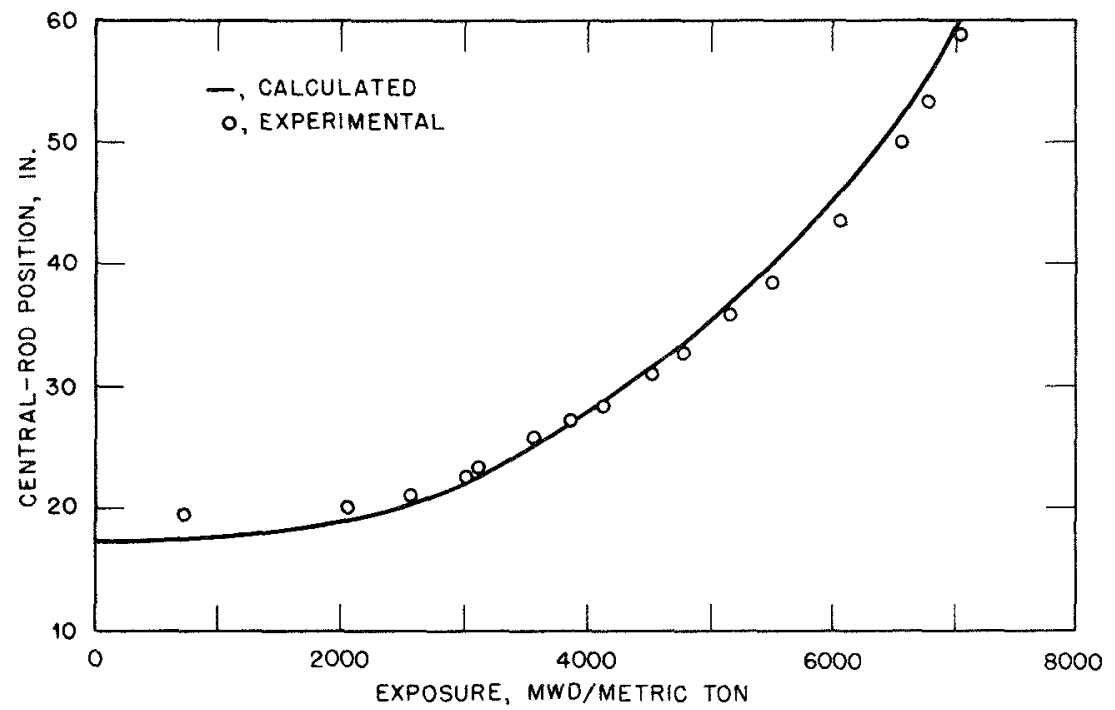

Fig 5-Graph shoung regulating-rod position vs. core exposure.

achieve as long a burnup as possible with reliance only on the movable rods for control and still maintain a reasonable time interval between refueling (1 year). This has resulted in a design burnup of the second core of about $14,500 \mathrm{Mwd} /$ metric ton.

\section{REFERENCES}

1. C. H. Westcott, Effective Cross Section Values for Well-moderated Thermal Reactor Spectra, Canadian Reports CRRP-680, Jan. 25, 1957, and CRRP-787 (1958 revision), Aug. 1, 1958; and C. H. Westcott and D. A. Roy, Supplement to Effective Cross Section Values for Well-moderated Thermal Reactor Spectra, Canadian Report CRRP-862, Aug. 20, 1959.

2. J. R. Fisher, Effective Neutron Cross Sections for Thorium-Uranium Fuel Cycles, Report CNRN-AC500-2, Allis-Chalmers Manufacturing Company, August 1960.

3. C. G. Campbell and R. G. Freemantle, Effective Cross Section Data for Thermal Reactor Calculations, Britısh Report AERE-RP/R-2031, August 1956.

4. B. Pershagen and I. Carlvik, Calculation of the Disadvantage Factor for the Moderator in a Cylindrical Lattice Cell, USAEC Report AEC-tr-3314, translated from Report AEF-69 (Swedish), Aktıebolaget Atomenerg1, Stockholm, Nov. 1, 1956.

5. G. D. Joanou and J. S. Dudek, GAM-I: A Consistent $P_{1}$ Multigroup Code for the Calculation of Fast Neutron Spectra and Multigroup Constants, USAEC Report GA-1850, General Atomic, Division of General Dynamics Corporation, June 28, 1961.

6. R. H. Shudde and J. Dyer, TEMPEST-II - A Neutron Thermalization Code, USAEC Report TID-18284, Atomics International Division, North American Aviation, Inc., June 1962. 
7. D. L. Delp, D. L. Fischer, J. M. Harriman, and M. J. Stedwell, FLARE-A Three-dimensional Boiling Water Reactor Simulator, USAEC Report GEAP4598, General Electric Company, July 16, 1964.

8. M. N. Audi, Fission Product Poisoning for Reactors of Various Spectra, Report ACNP-R.D. 47-19-158, Allis-Chalmers Manufacturing Company, February 1962. 